\title{
Condom use at first and latest sexual events among young people: evidence from a rural and peri-urban setting in Uganda
}

\author{
*Tumwesigye $\mathrm{NM}^{1}$, Ingham $\mathrm{R}^{2}$, Holmes $\mathrm{D}^{3}$
}

1. Makerere University College of Health Sciences, Department of Epidemiology and Biostatistics, School of Public Health

2. Centre for Sexual Health Research, University of Southampton

3. University of Southampton Division of Social Statistics,

\begin{abstract}
Background: Condom use remains low among young people despite high prevalence of HIV, STIs, and unplanned pregnancy in Uganda.

Objectives: This paper presents patterns of condom use at first and latest sexual events and associated factors.

Methods: The data were obtained from 445 sexually active unmarried people aged 15-24 from one peri-urban and another rural district. Stratified multi-stage cluster sampling technique was applied. Logistic regression was used to identify factors associated with condom use at each of the two sexual events, while multinomial logistic regression was used to establish factors correlated with condom use at both first and last sex.

Results: Factors associated with condom use at each event were residence in the peri-urban district and higher education attainment. Factors correlated with condom use at both first and last sex were residence in peri-urban district $(\mathrm{p}<0.001)$ and being in school $(\mathrm{p}<0.01)$. Alcohol consumption and age at first sex were only significant at one event.

Conclusion: Some factors that influence condom use at first sex are different from those that affect condom use at latest sexual event. Prevention programmes against STIs, HIV and unplanned pregnancies among young people focus more on rural areas and those with minimal or no education.
\end{abstract}

Key words: Multinomial logistic regression, dynamics of condom use, HIV, STI, STD, unplanned pregnancy

African Health Sciences 2013; 13(2): 407 - 414 http://dx.doi.org/10.4314/ahs.v13i2.30

\section{Introduction}

Condoms are a core component of basic HIV prevention services recommended by the World Health Organization ${ }^{1}$. When used consistently and correctly, the male condom is effective in reducing sexual transmission of HIV and STDs ${ }^{2}$. The importance of condoms can never be over emphasised especially at a time when prevalence of HIV, STD/STIs, and unplanned pregnancies are still unacceptably high in many countries. UNAIDS estimates that, as of December 2010, a total of 34 million people were living with HIV while 2.6 million were infected in the same year'.

Young people are among the most vulnerable group as more than half of new HIV infections occur among those aged below 25 years ${ }^{4}$. Unintended pregnancies lead to about 12,000

\section{*Corresponding author:}

Nazarius Mbona Tumwesigye

Department of Epidemiology and Biostatistics

School of Public Health

Makerere University College of Health Sciences

Tel: +25678244771

Email:naz@musph.ac.ug abortions among adolescents each day ${ }^{5}$. Correct and consistent use of condoms is the best way to prevent both pregnancy and disease ${ }^{6}$.

In Uganda, prevalence of condom use at first sex among unmarried young people aged 1524 has been reported to be $37 \%$ for females and $59 \%$ for males; while use at latest sex among the same age group is $54 \%$ for both males and females ${ }^{7}$. The prevalence of HIV in the general population has been $6.4 \%{ }^{7}$ but has risen ${ }^{8}$. Only a small proportion of sexually active young people can abstain for even 12 months?

Two of the best-recalled sexual events are the first and latest sex. There is a close association of condom use at first sex with lifetime condom use $^{10}$ and condom use at last sex is a reasonable proxy for consistent use as indicated by the high correlation between recency and frequenc ${ }^{11}$. This paper investigates condom use at first and last sex, and establishes factors associated with condom use at each of the events separately and at both events. Relatively little work has been done in this area. 


\section{Methods}

The data used in this study were obtained in May 2004 from 445 sexually active young people aged 15-24 in Mukono and Kabale districts in Uganda. Mukono is a peri-urban district with its headquarters located $27 \mathrm{~km}$ from the capital city, Kampala. It is on the highway to Uganda's second largest city, Jinja. Kabale is in extreme south west of the country, $420 \mathrm{~km}$ from Kampala. The district is largely rural, it is dependent on agricultural produce ${ }^{12}$.

A semi-structured questionnaire was used to collect the data. The respondents were randomly selected in a stratified multi-stage cluster survey. This involved use of simple random sampling technique to select sub-counties, parishes and villages, and systematic sampling to select a number of households that ranged from 4 to 14 per village.

The data on condom use were from questions on condom use at first and latest sex. Condom use was categorised in use at first and latest sex, use at only one of the two events and none-use at both events. Those whose first sex was at the same time the last sex were left out of the analysis that combined both times.

A chi-square test was used to test for equality of the proportion of condom use between levels of variables. Binomial logistic regression technique was used to model condom use at first and latest sex. Multinomial logistic regression was used to model condom use at the two events since the outcome resulted in more than two categories ${ }^{13}$ : condom use at the two events, use at one of the two and non-users at both events.
The model selection criteria used was based on work by Hosmer \& Lemeshow ${ }^{14}$ All variables with a $p$-value less than 0.2 in bivariate analysis were put in a model and a backward elimination procedure was followed. While in the multivariable model, variables with the highest $p$-value were removed one at a time until all had a Wald's test ${ }^{15} p$-value of less than 0.2. All variables not initially included in the model and those eliminated were also considered one at a time for any major positive influence by examining the changes in log likelihood on the model and the value of the log likelihood ratio test. Pearson's and Hosmer-Lemeshow's chi-square tests were also used to assess the goodness of fit of the models. Models were deemed well fit if there was minimal difference between observed and predicted values ${ }^{16}$ and hence higher $p$-values $(\mathrm{p}>0.05)$.

\section{Results}

\section{Description of the respondents}

Males were slightly more than females in the sample (males: $53 \%$, females 47\%). A higher proportion $(59 \%)$ of respondents was from Kabale while the rest (41\%) were from Mukono (table 1). Most of the respondents $(65 \%)$ were under 20 years of age; the females were much younger as $78 \%$ were aged $15-19$ compared to $53 \%$ for males $(\mathrm{p}<0.001)$. Nearly a half of them were in school and $62 \%$ had attained at least secondary education. Males were more likely to have attained secondary education than females $(\mathrm{p}=0.02)$. Most of the respondents $(81 \%)$ were Christians.

\section{Table 1: Characteristics of the respondents}

\begin{tabular}{|c|c|c|c|c|}
\hline Characteristics & Male n (\%) & Female n (\%) & All n (\%) & Chi-sq. p-value \\
\hline \multicolumn{5}{|l|}{ District } \\
\hline Mukono & $90(38.3)$ & $94(44.8)$ & $184(41.4)$ & 0.61 \\
\hline Kabale & 145 (61.7) & $116(55.2)$ & $261(58.7)$ & \\
\hline \multicolumn{5}{|l|}{ Age group } \\
\hline $15-19$ & $125(53.2)$ & $163(77.6)$ & $288(64.7)$ & $<0.001$ \\
\hline $20-24$ & $110(46.8)$ & $47(22.4)$ & $157(35.3)$ & \\
\hline \multicolumn{5}{|l|}{ In school } \\
\hline No/never & $113(48.1)$ & $107(51.0)$ & $220(49.4)$ & 0.55 \\
\hline Yes & $122(51.9)$ & $103(49.1)$ & $225(50.6)$ & \\
\hline \multicolumn{5}{|l|}{ Education } \\
\hline None/Primary & $77(32.8)$ & $92(43.8)$ & $169(38.0)$ & 0.02 \\
\hline Secondary and higher & $158(67.2)$ & $118(56.2)$ & $276(62.0)$ & \\
\hline \multicolumn{5}{|l|}{ Religion } \\
\hline Catholic & $91(38.7)$ & $77(36.7)$ & $168(37.8)$ & 0.98 \\
\hline Protestant & $100(42.6)$ & $92(43.8)$ & $192(43.2)$ & \\
\hline Muslim & $31(13.2)$ & $29(13.8)$ & $60(13.5)$ & \\
\hline Pentecostal/Evangelical & $13(5.5)$ & $12(5.7)$ & $25(5.6)$ & \\
\hline All & $235(52.8)$ & $210(47.2)$ & $445(100.0)$ & \\
\hline
\end{tabular}


Description of first and latest sexual events

A lower proportion of respondents (males, 66\%; females, 76\%) had first sex within an established relationship compared to latest sex (males, $82 \%$; females, $84 \%$ ) and this was more evident among males than females. Established relationship referred to girl/boyfriend or a known friend. Other relationship was casual or just a known person and a previously unknown or one time partner. The proportion that had sex within an established relationship was significantly higher among females than males $(p=0.03)$ at first sex but the difference was not significant at last sex.

Table 2: Description of first and latest sex events by gender

\begin{tabular}{|c|c|c|c|c|c|c|}
\hline \multirow[t]{2}{*}{ Variable } & \multicolumn{3}{|c|}{ First sex event } & \multicolumn{3}{|c|}{ Latest sex event } \\
\hline & Men (\%) & Women $(\%)$ & p-val & Men (\%) & Women (\%) & $\overline{\text { p-value }}$ \\
\hline Type of partner & $\mathrm{n}=235$ & $\mathrm{n}=210$ & & $\mathrm{n}=228$ & $\mathrm{n}=202$ & \\
\hline Girl/boy friend or known friend & 65.8 & 75.5 & & 82.0 & 84.2 & \\
\hline Casual (known but not friend) & 21.8 & 12.5 & 0.03 & 8.8 & 8.4 & 0.44 \\
\hline One time partner (unknown) & 12.4 & 12.0 & & 9.2 & 7.4 & \\
\hline Age difference with partner & $\mathrm{n}=221$ & $\mathrm{n}=181$ & & $n=226$ & $\mathrm{n}=177$ & \\
\hline Younger partner & 60.6 & 4.4 & $<0.001$ & 78.9 & 10.2 & $<0.001$ \\
\hline Same age & 16.3 & 5.0 & & 11.5 & 7.9 & \\
\hline Older (by $1-5$ years) & 21.3 & 60.8 & & 8.9 & 57.1 & \\
\hline Older (by $6+$ years) & 1.8 & 29.8 & & 0.9 & 24.9 & \\
\hline $\begin{array}{l}\text { When event occurred } \\
\text { (years before survey) }\end{array}$ & $\mathrm{n}=235$ & $\mathrm{n}=210$ & & $\mathrm{n}=228$ & $\mathrm{n}=202$ & \\
\hline Within 5 years & 76.3 & 88.1 & $<0.001$ & 91.7 & 95.5 & 0.64 \\
\hline Six + years & 23.7 & 11.9 & & 2.6 & 0.0 & \\
\hline Willingness & $\mathrm{n}=235$ & $\mathrm{n}=210$ & & $\mathrm{n}=228$ & $\mathrm{n}=202$ & \\
\hline Persuasion/coercion & 35.7 & 34.0 & 0.62 & 34.3 & 27.7 & 0.14 \\
\hline Both willing & 64.3 & 66.0 & & 65.6 & 72.3 & \\
\hline $\begin{array}{l}\text { Reason for use of condom } \\
\text { (Users only) }\end{array}$ & $\mathrm{n}=104$ & $n=122$ & & $\mathrm{n}=102$ & $\mathrm{n}=118$ & \\
\hline Did not want a child & 16.4 & 45.9 & $<0.001$ & 20.0 & 41.5 & $<0.001$ \\
\hline Avoid HIV & 76.9 & 48.4 & & 73.3 & 51.5 & \\
\hline Other & 6.7 & 5.7 & & 6.7 & 6.9 & \\
\hline $\begin{array}{l}\text { Reason for not using condom } \\
\text { (non-users only) }\end{array}$ & $\mathrm{n}=135$ & $\mathrm{n}=86$ & & $\mathrm{n}=135$ & $\mathrm{n}=130$ & \\
\hline Trusted partner & 32.6 & 17.4 & $<0.001$ & 34.8 & 22.5 & $<0.001$ \\
\hline Partner refused & 4.4 & 19.8 & & 8.7 & 25.4 & \\
\hline Other & 49.6 & 39.5 & & 51.1 & 33.8 & \\
\hline Don't know & 13.3 & 23.3 & & 5.4 & 18.3 & \\
\hline $\begin{array}{l}\text { Source of condoms } \\
\text { (Users only) }\end{array}$ & $\mathrm{n}=99$ & $\mathrm{n}=109$ & & $\mathrm{n}=92$ & $\mathrm{n}=71$ & \\
\hline Shop & 59.6 & 37.6 & $<0.001$ & 54.2 & 38.6 & $<0.001$ \\
\hline Private clinic/Drug shop & 21.1 & 23.9 & & 20.8 & 25.4 & \\
\hline Health centre & 2.0 & 6.4 & & 12.5 & 7.0 & \\
\hline Don't know & 3.0 & 22.9 & & 0.8 & 21.9 & \\
\hline Other & 2.0 & 9.2 & & 11.7 & 7.0 & \\
\hline
\end{tabular}


A much higher proportion of males had younger partners at first and latest sex. The proportion that had younger partners had increased by latest sex for both males $(61 \%-79 \%)$ and females $(4 \%-10 \%)$ but the increase was more significant among males $(\mathrm{p}<0.01)$ than females $(\mathrm{p}=0.035)$.

Females had longer exposure to sex compared to males as $88 \%$ had their first sex in previous 5 years compared to $76 \%$ for males $(\mathrm{p}<0.001)$. Nearly all $(>91 \%)$ had latest sex in previous 12 months. A little over one third of the males and females reported having been coerced or persuaded by their partners to have first sex but this did not change significantly by last sex.

The major reasons for using condoms were avoiding HIV and pregnancy; while the main reasons for not using condoms were related to trust and refusal by the partner. At last sex, $73 \%$ of males and $52 \%$ of females used condoms to avoid HIV; while $20 \%$ of males and $42 \%$ of females wanted to avoid pregnancy. The reported sources of condoms were shops, private clinic/drug shops and health centres. Females were more likely to report lack of knowledge of sources of condoms than males.

\section{Reported levels of condom use at first and latest sexual events}

Table 3 shows levels of condom use by gender. Overall, half of the respondents used a condom at first sex, with females reporting a higher level of use
$(59 \%)$ than males $(43 \%)(\mathrm{p}<0.001)$. The difference in condom use by sex was not significant at latest sex, as $57 \%$ of males and $55 \%$ of females used condoms. The level of condom use was higher in Mukono than in Kabale at both first and latest sexual events $(p<0.01)$. Higher age at first sex $(15-24$ years $)$ was significantly correlated with condom use at first sex among males and females $(p<0.01)$ but not at last sex.

Condom use at first and latest sex was higher among those in school, those who had attained secondary education and those who listened to radio but this was more evident among females. Those who attended private schools were more likely to use condoms than those who attended religious and government founded schools, but this was only significant at last sex $(p<0.05)$. The level of condom use among Muslim and Evangelical females was higher than others $(p<0.01)$ but they were few in the sample.

Sex with girl/boyfriend, sex without coercion and recent relationship were associated with condom use at both first $(\mathrm{p}<0.001)$ and latest events $(\mathrm{p}<0.001)$ while non-use of alcohol was only associated with condom use at latest event. Access to newspapers/magazines and communication with parents about sexual matters, length of stay at place of residence and residing with parents were not significantly associated with condom use at first and latest sex.

Table 3: Levels of Condom use at first and latest sexual activity by gender

\begin{tabular}{|c|c|c|c|c|c|c|}
\hline \multirow[b]{2}{*}{ Variable } & \multicolumn{3}{|c|}{ Men } & \multicolumn{3}{|c|}{ Women } \\
\hline & $\mathbf{n}$ & First $\%$ & Last & () $\mathbf{n}$ & First $(\%)$ & Last $(\%)$ \\
\hline District & & $* *$ & $* * *$ & & $* * *$ & $* *$ \\
\hline Kabale & 145 & 31.1 & 33.7 & 116 & 31.9 & 43.3 \\
\hline Mukono & 90 & 50.3 & 71.9 & 94 & 81.0 & 64.3 \\
\hline Age group & & & & & & $*$ \\
\hline $15-16$ & 34 & 26.5 & 53.1 & 67 & 62.7 & 63.5 \\
\hline $17-18$ & 57 & 42.1 & 54.7 & 66 & 57.6 & 55.6 \\
\hline $19-20$ & 58 & 50.0 & 63.8 & 46 & 54.4 & 44.4 \\
\hline $21-22$ & 51 & 52.9 & 64.0 & 16 & 75.0 & 56.3 \\
\hline $23-24$ & 35 & 34.3 & 42.9 & 15 & 46.7 & 46.7 \\
\hline Age at first sex (years) & & $* * *$ & & & $* *$ & \\
\hline$<15$ & 72 & 18.1 & 51.5 & 71 & 40.9 & 48.5 \\
\hline $15-24$ & 160 & 54.4 & 59.9 & 139 & 68.4 & 58.1 \\
\hline In school & & & & & $* *$ & $* * *$ \\
\hline No & 113 & 39.8 & 54.6 & 107 & 49.5 & 37.5 \\
\hline Yes & 122 & 45.9 & 59.2 & 103 & 68.9 & 73.5 \\
\hline Education level & & & $* *$ & & $* *$ & $* *$ \\
\hline None/ry & 158 & 36.4 & 43.8 & 118 & 45.7 & 35.3 \\
\hline Secondary & 77 & 46.2 & 63.2 & 92 & 69.5 & 69.2 \\
\hline
\end{tabular}




\begin{tabular}{|c|c|c|c|c|c|c|}
\hline \multirow[b]{2}{*}{ Variable } & \multicolumn{3}{|c|}{ Men } & \multicolumn{3}{|c|}{ Women } \\
\hline & $\mathbf{n}$ & First $(\%)$ & Last $(\%)$ & $\mathbf{n}$ & First $\%)$ & Last $\left.{ }^{\%}\right)$ \\
\hline District & & ** & $* * *$ & & $* * *$ & $* *$ \\
\hline School attended & & & $* *$ & & & $*$ \\
\hline Public & 90 & 44.4 & 53.4 & 85 & 50.6 & 44.9 \\
\hline Religious & 51 & 35.3 & 40.8 & 59 & 66.1 & 61.0 \\
\hline Private/Unknown & 94 & 47.1 & 71.4 & 54 & 68.5 & 69.8 \\
\hline Listens to radio & & & & & $* *$ & $* *$ \\
\hline No & 12 & 34.6 & 48.0 & 32 & 44.3 & 37.3 \\
\hline Yes & 223 & 44.0 & 58.1 & 178 & 65.1 & 62.2 \\
\hline Religion & & & & & $* *$ & \\
\hline Catholic & 91 & 41.8 & 52.3 & 77 & 53.3 & 51.4 \\
\hline Protestant & 100 & 42.0 & 56.6 & 92 & 53.3 & 52.2 \\
\hline Moslem & 31 & 45.2 & 57.1 & 29 & 82.8 & 69.2 \\
\hline Pentecostal/Evangelical & 13 & 53.9† & 92.3 & 12 & 83.3 & 66.7 \\
\hline Drinks alcohol & & & $* *$ & & & \\
\hline No & 149 & 47.7 & 65.5 & 160 & 62.5 & 52.6 \\
\hline Yes & 86 & 34.9 & 43.0 & 50 & 48.0 & 62.0 \\
\hline \multicolumn{7}{|l|}{ Length of stay at residence } \\
\hline$<=5$ years & 128 & 47.7 & 57.7 & 127 & 68.7 & 51.9 \\
\hline$>5$ years & 107 & 39.5 & 50.8 & 83 & 52.8 & 55.6 \\
\hline \multicolumn{7}{|l|}{ Resides with } \\
\hline Both parents & 105 & 40.0 & 53.5 & 83 & 51.8 & 60.3 \\
\hline Single parent & 52 & 46.2 & 53.1 & 72 & 62.5 & 55.1 \\
\hline Grandparents/other & 77 & 45.5 & 53.6 & 55 & 65.5 & 45.3 \\
\hline Willingness to have $1^{\text {st }}$ sex & & & & & $* * *$ & \\
\hline Involved persuasion/force & 84 & 44.1 & 53.9 & 71 & 42.3 & 60.0 \\
\hline Both willing & 148 & 42.0 & 53.6 & 138 & 67.4 & 54.4 \\
\hline Girl/Boyfriend/friend & 188 & 53.9 & 57.8 & 174 & 69.0 & 57.4 \\
\hline Casual/One time partner & 47 & 21.3 & 35.0 & 36 & 28.9 & 38.7 \\
\hline When $1^{\text {st }}$ sex took place & & $* * *$ & & & $* * *$ & $*$ \\
\hline Within 1 year ago & 77 & 54.6 & 54.9 & 135 & 69.1 & 57.0 \\
\hline $2-5$ years ago & 100 & 50.0 & 57.0 & 50 & 57.1 & 33.3 \\
\hline $6+$ years ago & 55 & 14.6 & -- & 25 & 8.0 & -- \\
\hline Attitude to condom use & & & & & $* * *$ & $* *$ \\
\hline Low/medium & 99 & 40.4 & 51.6 & 108 & 61.1 & 51.5 \\
\hline High & 107 & 46.7 & 65.4 & 65 & 69.2 & 71.9 \\
\hline Incomplete score & 29 & 37.9 & 44.8 & 37 & 35.1 & 35.1 \\
\hline All & 235 & 43.0 & 57.0 & 210 & 59.1 & 55.0 \\
\hline
\end{tabular}

Comparing influences on first sex and last sex Table 4 shows that being from Mukono and higher level of education were the only factors independently associated with condom use at both first and latest sex. Starting sex late was strongly associated with condom use at first but not at last sex. Listening to radio was correlated with condom use at last sex but it was not significant at first sex. While age was a significant factor for condom use at first sex, it was only influential among males. Conversely, listening to radio and a higher level of education were only significant among females at latest sex.
Pattern of use at both first and last sex

Forty per cent used condoms at both first and latest sex event while $27 \%$ used them at only one of the two events, and 33\% never used them. With nonuse of condom as the base, multinomial logistic regression model showed that those who resided in Mukono and school going females were more likely to use condoms at both first and last sex events than residents of Kabale and non-school going females. The model further shows that residents of Mukono and female alcohol consumers were more likely to use condoms at only one of two events compared to residents of Kabale and female non-alcohol consumers. 
Table 4: Factors correlated with condom use at first and latest sex

\begin{tabular}{|c|c|c|c|c|}
\hline \multirow[t]{2}{*}{ Covariates } & \multicolumn{2}{|c|}{$\begin{array}{c}\text { Condom use at } \\
\text { first sex }\end{array}$} & \multicolumn{2}{|c|}{ Condom use at latest sex } \\
\hline & $\begin{array}{l}\text { Men } \\
\text { OR }\end{array}$ & $\begin{array}{l}\text { Women } \\
\text { OR }\end{array}$ & $\begin{array}{l}\text { Men } \\
\text { OR }\end{array}$ & $\begin{array}{l}\text { Women } \\
\text { OR }\end{array}$ \\
\hline \multicolumn{5}{|l|}{ District (base $=$ Kabale) } \\
\hline Mukono & $\begin{array}{c}3.01 \\
(1.52-5.96)^{* *}\end{array}$ & $\begin{array}{c}10.88 \\
(2.98-39.79)^{* *}\end{array}$ & $\begin{array}{c}3.62 \\
(1.76-7.45)^{* * *}\end{array}$ & $\begin{array}{c}1.62 \\
(0.87-3.03)\end{array}$ \\
\hline \multicolumn{5}{|l|}{ Age at first sex (Base $<15$ years) } \\
\hline $15-24$ & $\begin{array}{c}2.86 \\
(1.43-5.70)^{* *}\end{array}$ & $\begin{array}{c}2.86 \\
(0.85-9.68)\end{array}$ & $\begin{array}{c}1.09 \\
(0.49-2.42)\end{array}$ & $\begin{array}{c}0.98 \\
(0.50-1.90)\end{array}$ \\
\hline \multicolumn{5}{|l|}{$\begin{array}{l}\text { Education level } \\
\text { (Base=Non/primary) }\end{array}$} \\
\hline Secondary & $\begin{array}{c}2.06 \\
(1.06-4.00)^{*}\end{array}$ & $\begin{array}{c}5.86 \\
(1.76-19.51)^{* *}\end{array}$ & $\begin{array}{c}2.09 \\
(0.97-4.52)\end{array}$ & $\begin{array}{c}3.21 \\
(1.73-5.96)^{* * *}\end{array}$ \\
\hline \multicolumn{5}{|l|}{ Listens to radio $($ Base $=\mathrm{No})$} \\
\hline Yes & $\begin{array}{c}1.45 \\
(0.38-5.56)\end{array}$ & $\begin{array}{c}0.24 \\
(0.06-1.08)\end{array}$ & $\begin{array}{c}0.69 \\
(0.15-3.31)\end{array}$ & $\begin{array}{c}0.28 \\
(0.11-0.72)^{* *}\end{array}$ \\
\hline \multicolumn{5}{|c|}{ Type of partner $($ base $=$ Girl $/$ boyfriend $/$ friend $)$} \\
\hline Casual/one time partner & $\begin{array}{c}0.96 \\
(0.67-1.37)\end{array}$ & $\begin{array}{c}0.76 \\
(0.40-1.46)\end{array}$ & $\begin{array}{c}0.66 \\
(0.26-1.67)\end{array}$ & $\begin{array}{c}0.65 \\
(0.27-1.59)\end{array}$ \\
\hline \multicolumn{5}{|c|}{ Condom use at first sex $($ Base $=$ no $)$} \\
\hline Yes & & & $\begin{array}{c}11.80 \\
(5.67-24.59)^{* * *}\end{array}$ & ++ \\
\hline Goodness of fit $\chi^{2}$ test $p$-value & 0.36 & 0.45 & 0.17 & 0.15 \\
\hline
\end{tabular}

$* \mathrm{p}<0.05 * * \mathrm{p}<0.01 * * * \mathrm{p}<0.001$

++ Not included in model due high confidence interval (OR=54.6 95\%CI: 15.89-183.16) which causes undue confounding effects to other variables

Table 5: Predicted probabilities of condom use at both first and latest sexual events from a multinomial logit model

\begin{tabular}{|c|c|c|c|c|c|c|}
\hline \multirow[t]{2}{*}{ Variable } & \multicolumn{3}{|l|}{ Men } & \multicolumn{3}{|l|}{ Women } \\
\hline & $\begin{array}{l}\text { Used at both } \\
\text { events }(\%)\end{array}$ & $\begin{array}{l}\text { Used at } \\
\text { one event } \\
(\%)\end{array}$ & $\begin{array}{l}\text { Did not } \\
\text { use at both } \\
\text { events }(\%)\end{array}$ & $\begin{array}{l}\text { Used at both } \\
\text { events }(\%)\end{array}$ & $\begin{array}{l}\text { Used at one } \\
\text { event }(\%)\end{array}$ & $\begin{array}{l}\text { Did not } \\
\text { use at both } \\
\text { events }(\%)\end{array}$ \\
\hline District & $* * *$ & ** & & $* * *$ & ** & \\
\hline Kabale & 21.4 & 22.6 & 56.0 & 29.1 & 16.3 & 54.6 \\
\hline Mukono & 45.0 & 32.9 & 22.1 & 58.1 & 29.2 & 12.7 \\
\hline Alcohol & & & & & $* *$ & \\
\hline No & 42.4 & 28.7 & 28.8 & 47.4 & 20.0 & 32.5 \\
\hline Yes & 24.7 & 29.4 & 45.9 & 38.0 & 34.0 & 28.0 \\
\hline In School & & & & $* *$ & & \\
\hline No & 32.3 & 30.1 & 37.6 & 27.3 & 32.0 & 40.7 \\
\hline Yes & 39.3 & 27.9 & 32.8 & 63.7 & 14.4 & 21.9 \\
\hline \multicolumn{7}{|l|}{ Education } \\
\hline None/ry & 27.5 & 25.7 & 46.8 & 28.4 & 24.9 & 46.7 \\
\hline Secondary & 39.9 & 30.5 & 29.6 & 58.1 & 22.2 & 19.6 \\
\hline \multicolumn{7}{|c|}{ Age at first sex } \\
\hline$<15$ & 17.8 & 35.2 & 46.9 & 35.6 & 17.8 & 46.7 \\
\hline $15-24$ & 44.1 & 26.1 & 29.7 & 50.0 & 26.3 & 23.7 \\
\hline
\end{tabular}

$* \mathrm{p}<0.05 * * \mathrm{p}<0.01 * * * \mathrm{p}<0.001$ 


\section{Discussion}

This study has established that factors associated with condom use are residence in Mukono, higher age at first sex, higher level of education, being in an established relationship with the partner and studying in private schools. However, not all these factors were significant at both first and latest sex. Condom use at both first and latest was correlated with residence in Mukono and being female.

Higher reported level of condom use at first sex among females than males has been reported in other research ${ }^{17}$. In this study, the difference was greater in Mukono than in Kabale. One explanation could be the age difference with sexual partner and kind of partner. In Mukono, females were more likely to have had first sex within an established relationship and with older partners, both of which were associated with condom use.

Higher level of condom use at both first and latest sex in Mukono than Kabale is a reflection of gaps in access and use of condoms between periurban and rural areas of the country.

Increase in condom use with age at first sex is not surprising as it is in agreement with previous findings ${ }^{18}$ but it is not clear why this was not significant among females.

The relationship between level of education and condom use at first sex is also supported by other research findings ${ }^{18}$, although it was only significant among females. This is consistent with previous findings in Uganda ${ }^{19}$ and Ghana ${ }^{20}$. Being in school was only significant among females at both first and latest sex. This needs further research.

A higher level of condom use among those who studied in private schools compared to public schools may be explained by different approaches to health education but more research is needed to explain the difference.

Higher likelihood of condom use at both first and latest sex among those in an established relationship compared to those in casual relationships is both consistent and inconsistent with other studies. In some studies, condom use at first sex was strongly associated with established relationship ${ }^{21}$ while in others it was strongly associated with casual relationship ${ }^{22}$. Some researchers have reported that young people were more likely to use condoms at latest sex in casual than in steady partnerships ${ }^{23}$ [. A study in Zimbabwe found that, among males, the likelihood of condom use at last sex with a casual partner was nearly the same as that with a steady partner ${ }^{24}$. Further research may investigate the role of use of other contraceptive methods on condom use.

Results of association of inconsistency of condom use at first and latest sex events with alcohol consumption are similar to findings from other research ${ }^{25}$. Loss of self-control resulting from alcohol consumption is a factor in non-use of condoms at one of the events.

Differences in factors that correlated with condom use at first and latest sex were also highlighted in a similar study in the United States ${ }^{26}$.

\section{Conclusion}

Factors that influence condom use at first sex are not necessarily the same for latest sex and vice-versa. Programmes meant to improve condom use need to consider these differences and give priority to rural areas and young people with minimal or no education.

More research is needed to investigate the dynamics of condom use at first and latest sex especially as they relate to rural and urban settings. Cohort studies are recommended to minimise memory failure and allow adjustment for independent factors that change over time.

\section{Limitations}

Investigators recognise limitations of memory lapses and change of predisposing factors to condom use with time. It is difficult to recall events at first sex and factors such as listening to radio may have changed over time.

\section{Acknowledgements}

The authors are grateful for financial support from Makerere University, Uganda; Opportunities and Choices Programme of the Division of Social Statistics and Safe Passages to Adulthood Programme in the School of Psychology, University of Southampton. Both programmes at the University of Southampton were supported by the Department for International Development, UK Government.

\section{References}

1. CDC, Update: barrier protection against HIV infection and other sexually transmitted diseases. MMWR -Morbidity and Mortality Weakly Report 1993; 42: 589-91.

2. Steiner MJ, Cates W. Condoms and SexuallyTransmitted Infections. New England Journal of Medicine 2006; (354): 2642-2643. 
3. UNAIDS, Report on global AIDS epidemic, Geneva: UNAIDS; 2010

4. Youthnet and FHI, Sexuality and family life education, Research Triangle Park, NC: Family Health International; 2005

5. UNFPA, Fast facts. Young people and demographic trends, New York: UNFPA; 2000

6. McNeill, E.T., Gilmore, C.E., Finger, W.R., Lewis JH, Schellstede WP. The Latex Condom: Recent Advances, Future Directions, New York: Family Health International; 2008

7. $\mathrm{MOH}$ and ORC Macro, Uganda HIV/AIDS Sero-behavioural Survey 2004-2005 Calverton, Maryland, USA: Ministry of Health and ORC Macro 2006

8. Shafer L, Biraro S, Nakiyingi-Miiro J, Kamali A, Ssematimba, D, Ouma J et al. HIV prevalence and incidence are no longer falling in southwest Uganda: evidence from a rural population cohort 1989-2005. AIDS 2008; 22: 1641-1649.

9. Tumwesigye NM, Ingham R, Holmes D. The dynamics of secondary abstinence among unmarried young people: analysis of event history calendar data from Kabale and Mukono districts in Uganda. African statistics Journal, 2008; 6:67-86

10. Miller KS, Levin ML, Whitaker DJ, nd Xu, X. Patterns of condom use among adolescents: the impact of mother-adolescent communication. American Journal of Public Health 1998; 88: 1542-1544.

11. Cleland J, Boerma T, Carael M, Weir SS. Monitoring sexual behaviour in general populations: a synthesis of lessons of the past decade. Sexually Transmitted Infections 2004; 80: 1-7.

12. KDLG, State of the environment report for Kabale district Kabale: Kabale district local government; 2004

13. Petrucci CJ. A Primer for Social Worker Researchers on How to Conduct a Multinomial Logistic Regression. Journal of social service research, 2009; 35(2): 193 - 205

14. Hosmer DW, Lemeshow S. Applied logistic regression. 1989, New York: John Wiley and Sons.

15. Hauck WW, Donner A. Wald's test as applied to hypothesis in logit analysis. Journal of the american statistical association, 1977; 72(360): 851 $-853$

16. Hosmer DW, Hosmer T, Le Cessie S. A comparison of goodness-of-fit tests for then logistic regression model. Statistics in Medicine, 1997; 17: 965-980.

17. Levin ML, Robertson AA. Being prepared: Attitudes and practices related to condom carrying among minority adolescents. Journal of HIV/AIDS Prevention \& Education for Adolescents \& Children 2004; 5(1/2): 103-121.

18. Abma JC, Sonenstein FL. Sexual activity and contraceptive practices among teenagers in the United States, 1988 and 1995. Vital and Health Statistics 2001; 23(21): 1-88.

19. Najjumba MI, Ntozi PMJ, Ahimbisibwe EF, Odwe J, Ayiga N.Risk perception and condom use in Uganda. African Population Studies 2003; 18(1): 67-80.

20. Karim AM, Magnani RJ, Morgan GT, Bond KC. Reproductive health risk and protective factors among unmarried youth in Ghana. International Family Planning Perspectives 2003; 29(1): 14-24.

21. Manlove J, Terry-Humen E, Papillo AR, Franzetta K, Williams S, Ryan S, Background for community-level work on positive reproductive health in adolescence: Reviewing the literature on contributing factors Washington: Child Trends Inc; 2001

22. Forste R, Haas DW., The transition of adolescent males to first sexual intercourse: Anticipated or delayed? Perspectives on Sexual and Reproductive Health 2002; 34(4): 184-190.

23. Lansky A, Thomas JC, Earp JA. Partnerspecific sexual behaviors among persons with both main and other partners. Family Planning Perspectives 1998; 30: 93-96.

24. Adetunji J, Meekers D. Consistency in condom use in the context of HIV/AIDS in Zimbabwe. Journal of Biosocial Science 2001; 22: 121-138.

25. Wee S, Barrett ME, Lian WM, Jayabaskar T, Chan KW. Determinants of inconsistent condom use with female sex workers among men attending the STD clinic in Singapore. Sexually Transmitted Infections 2004; 80(4): 310314.

26. Manlove J, Ikramullah E, Terry-Humen E, Condom Use and Consistency Among Male Adolescents in the United States. Journal of adolescent health, 2008; 43(4): 325-333. 